RESEARCH ARTICLE

\title{
Mediated Deliberation in Deep Conflicts: How Might Deliberative Media Content Contribute to Social Integration Across Deep Divides?
}

\author{
Charlotte Löb and Hartmut Wessler
}

Conflicts perceived by the media, either within or across national borders, are a staple of modern societies. These conflicts become especially challenging for societies that are divided along religious, ethnic, cultural or political lines. In the light of such deep conflicts, the contribution of mediated deliberation to social integration moves center stage. In this paper we discuss normative standards for mediated public communication deemed conducive to social integration in divided societies by deliberative theorists. We identify inclusiveness, responsiveness, mutual respect, and the display of group-bridging identities as the essential criteria. These criteria can be applied as yardsticks to assess the production, the content as well as the reception of media material in both mass media and social media. They therefore serve as an ideal point of departure for empirical work on the media's role in social integration.

Keywords: deliberation; conflict; divided society; social integration; media; public sphere

"One of the deepest divides in America today is the gulf of mutual suspicion that separates evangelicals from secular society, and policy battles over abortion and judicial appointments will aggravate these tensions further in coming months" (Kristof, 2003).

Even after nearly 20 years this statement has not lost its relevance. It characterizes a central phenomenon that is not confined to the U.S. Conflicts within a society caused by religious, ethnic, cultural, or linguistic diversity are central issues of various modern societies. Together with prevalent political polarization tendencies, these conflicts can lead to nearly unbridgeable cleavages: For the U.S., Iyengar et al. (2019) have, for example, traced the growing division of the American society back to opposing social identity groups (i.e., Republicans and Democrats). Deep divisions sometimes even result in violent conflicts between social groups such as Catholics and Protestants in Northern Ireland (1960s-1998).

Societies that are characterized by such "mutually contradictory assertions of identity" (Dryzek, 2005, p. 219) are considered divided societies. Such a divide might be manifested in the U.S., for example, in policy battles over issues such as abortion, same-sex marriage, etc. These issues are also contested in undivided or less deeply divided societies. In divided societies, different assertions of identities are not only mutually exclusionary

Institute for Media and Communication Studies, University of Mannheim, Mannheim, DE

Corresponding author: Charlotte Löb

(charlotte.loeb@googlemail.com) but also more salient personally and socially than in nondivided societies. The resulting cleavage fundamentally structures public life and public discourse, with the result that a compromise or consensus seems out of reach. For U.S. evangelicals, for example, whose religious affiliation constitutes the cornerstone of their identity, accepting practices like same-sex marriage might be experienced as a major offense against their group identity. Thus, even a "compromise" of exclusively restricting same-sex marriage to civil marriage would threaten deeply held convictions and the basis of their group identity.

In divided societies conflicting identity groups rarely engage in constructive, problem-solving discourse. But does this also mean that there is no hope for integration and convergence of the different groups? Are divided societies doomed to either civil war or outright segregation? Or might there actually be a chance of integration built into, or at least fostered by, specific ways of communicating in and about deep conflicts?

Based on deliberative theories of democracy (Kanra, 2016; O'Flynn, 2006) we aim at carving out the constructive potential of conflict for social integration. We first take up relevant lines of thought from sociological conflict theory, which highlight the positive aspects of conflicts. In a second step, we focus on mediated public debates as the most important arena of public discourse in democratic societies and elaborate on how some forms of mediated conflict communication might contribute to social integration. In a last step, we specify key deliberative criteria that may help assess the integrative potential of mediated public discourse in deep conflicts. We show how these criteria might be applied in future empirical studies. 


\section{Social Integration Through Conflict Communication}

The term "integration" originates from the Latin word "integrare" which translates into "combine (one thing) with another to form a whole" (integrate 2017). The term can be used in different ways. It can describe the process of integrating something or someone and it can be used as a success term (Peters, 2008a) that describes the result of making something whole (again) (Imbusch \& Rucht, 2005, p. 19). We use integration as a success term. In modern societies, two modes of successful integration must be distinguished (Lockwood, 1970): social integration, which revolves around processes of plural differentiation between social groups (Peters, 1993) and systemic integration, which responds to the functional differentiation of societal subsystems following different systemic logics.

Plural differentiation expresses itself in the existence of symbolic communities or large collectives that are based on specific definitions of collective identity which have a diffuse effect on all aspects of life and the individual identities of its members (Peters, 1993, p. 197). Within this perspective, integration is seen as one, if not the most important problem that modern societies must continually solve: As societies change over time and face new economic/social or political challenges so do identity-defining symbolic communities within a society.

The logic of systemic integration conceptualizes society-wide differentiation as functional (cf. Luhmann, 1996; Luhmann, 2008; Parsons, 1958) and refers to the relationship between different subsystems within a society. Systemic integration does not require purposeful communicative action to establish specific relations to particular others because their relations are governed by abstract functional imperatives enacted through the adoption of specific roles: In the political system, for example, individuals participate as voters, in the economic system they act as consumers or employees.

In contrast to systemic integration, social integration refers to relations between social actors (Lockwood, 1970, p. 125). It embraces different kinds of social relations as well as integration of individuals into various types of symbolic communities such as family or sports clubs as well as society as a whole (Peters, 1993, p. 197). Peters (1993, p. 198) distinguishes symbolic communities that are of central significance for the identity of their members from those that have mere peripheral, transitory or ornamental meanings. It is the first type, which we call identity-defining symbolic communities, that is most relevant for social (dis)integration. Such identity-defining communities mostly build on religious, ethnic, cultural, linguistic or political divisions and are often socially normalized, psychologically salient and relatively stable over time, albeit not immutable. Their reproduction and evolution are contingent on discursive processes, including mediated public communication, in which elements of collective identity are continually confirmed as well as partially questioned and amended.

Relations between identity-defining symbolic communities can either be appreciative, indifferent or conflictive. Appreciation and even indifference can count as integrative resources in pluralistic societies. Indifference simply means that certain domains in a symbolic community's lifeworld neither disturb nor delight other groups. Some cultural practices, in particular those that take place in the private realm, are then treated with benevolent disinterest. Because successful social integration is manifested in the existence of an overarching identity-defining symbolic community that serves as counter-balance to the various group identities, conflictual relations between symbolic communities are prima facie more problematic. If mutually excluding group identities are particularly salient, as it is the case in divided societies, the overarching identity-defining symbolic community will not be salient enough to balance the differences between the group identities (cf. O'Flynn, 2006, p. 32).

The idea that group conflict and conflict communication serve as a motor for social integration might sound counter-intuitive at first, inter alia because the more intuitive understanding of integration is predicated on harmony or the nonexistence of conflict. But there is a tradition within social theory that builds on the idea of "contained" conflicts and highlights their integrative potential for societies. Building on a classification by Hirschman (1994), Dubiel (1999) defines the spectrum of social conflict between two extremes: (a) civil war - a pure form of identity conflict in which the enemies deny each other the right to exist and which would lead to the extermination of at least one of the conflicting parties; (b) strategic competition of interests regulated by familiar and shared settlement rules.

Situated between those poles, social conflicts are defined by robust but contained forms of dispute. Conflicts in this sense should reflect the deeper concerns of each party, but the opponents' conduct should also be constrained by rules that emerge in the very exchange itself (Dubiel, 1999, p. 141). In conflicts like these the opponents (a) know and acknowledge each other, (b) do not see each other as enemies but as legitimate opponents, and (c) embrace their dispute as necessary (see also Mouffe, 2013). Such conflicts result in a consciousness of a commonly shared political and social space.

The dominant form of conflict in democratic public spheres is that of internal critique. Citizens mutually accuse each other of deviating from principles and norms whose validity they simultaneously recognize. Therefore, the permanent public dispute indirectly affirms and also expands the stock of normative commonalities. (Dubiel, 1997, p. 442; translation by the authors)

This common space is neither identical to an agreement on tradition-based values, which is more than outdated in the context of heterogeneous modern societies, nor is it equal to substantive consensus achieved through prior discussion. Symbolic resources that can integrate modern societies facing deep conflicts are produced through the process of living through intense conflicts for which no predetermined mechanisms of interest 
alignment yet exist. However fruitful this line of thought may be for our purpose, it remains unclear where and how these symbolic resources are created that promise to foster social integration. The next sections will therefore discuss mediated public spheres as suitable "locations" for integrative conflict communication and its normatively desired features. ${ }^{1}$

\section{Mediated Public Spheres and Conflict Communication}

Without public spheres and a public discourse in which ideas and positions are exchanged, different groups within a society would hardly consider the needs and problems of other groups, and social integration would be impossible. Such consideration of others' perspectives is a basic feature of democracy. Because public discourse is largely mediated (Page, 1996, p. 1) the media can be seen as key actors for social integration in democratic societies (Brüggemann et al., 2009).

However, mediated discourse is not per se integrative. In conflicts that turned violent during the last decades, the role media coverage played is quite depressing: In the field of conflict studies the role of media coverage in places like the former Yugoslavia, Rwanda or Northern Ireland for the relations between the conflicting groups as well as the progression of the conflict as a whole has been analyzed (see, for example, Kellow \& Steeves, 1998; Thompson \& Annan, 2007; Wolfsfeld, 2004). Media coverage of the respective political issues or social problems did generally not support a peaceful reconciliation of differences. Instead, the media often seemed to exacerbate conflicts between different identity groups. The cases in which mediated discourse actually contributed to de-escalation and integration are grandly outweighed by examples in which it fueled the conflict. However, there may be a sampling bias involved as studies in conflict communication usually choose the more drastic cases. We contend that mediated discourse on group conflicts need not per se undermine social integration. In the next section, we will therefore turn to literature that discusses conditions and standards for journalists and mediated discourses in general under which media discourse might contribute to the deconstruction of antagonistic group identities.

\section{Normative Benefits of (Mediated) Conflict Communication}

Different strands of communication research have asked which kind of conflict communication would contribute to reconciliation or de-escalation. Within journalism research alternative conceptions of journalism have evolved (Mast et al, 2019): "peace journalism" (e.g., Keeble et al., 2010; Lynch \& Galtung 2010), "public journalism" (e.g., Ahva, 2012; Rosen et al., 1997), or quite recently "constructive journalism" (e.g., Bro, 2019; Hermans \& Gyldensted, 2018). All of these concepts promote journalistic practices that are more inclusive and multiperspectival than the "classical", fact-centered approach. Therefore, they concur with our intentions and can partly be integrated in a more general theoretical framework that establishes normative criteria for successful social integration through conflict communication.
Conflict communication is an important issue for many established normative democratic theories, but it is defined and valued differently (Held, 2006), depending on the respective understanding of public spheres and the functions attributed to them. Of the different normative theories (see e.g., Baker, 2002; Ferree et al., 2002; Held, 2006) the deliberative tradition most clearly locates social integration at the level of public discourse. It does so by identifying the public problematization of value claims as a central ingredient in mediated discourse, and sets specific standards on how such problematization should be processed, instead of banning it from public discourse as, for example, the liberal tradition does (Baker, 2002; Wessler, 2018). In order to identify the integrative potential that the deliberative tradition sees in particular forms of conflict communication we will first describe the notion of deliberative theory in general:

The deliberative model of democracy, which is mainly based on works by Habermas (1994b; 1996), combines elements of both the liberal and the republican tradition. It represents a procedural concept of decision making, translating "universal human rights... into the rules of discourse and forms of argumentation" (Habermas, 1994b, p. 6). Deliberation, the process of actively listening and responding to arguments of opponents (Habermas, 1996) is the core value of this perspective. Of particular importance are the preconditions of a deliberative discourse: It requires civility and mutual respect between discussants and the willingness to engage in dialogue, by providing arguments and responding to reasons of others (Ferree et al., 2002, pp. 218-219). Especially mutual respect constitutes the ethical function of deliberation (Mansbridge et al., 2012, p. 11).

Regarding the participants of a public discourse, the original deliberative demand is the inclusion of all actors affected by the issue at hand. As an alternative, openness (i.e., equal opportunities) for issues, perspectives, interpretations, ideas, and arguments has been suggested (Peters, 2008b). This aspect of deliberation represents the democratic function of deliberative discourse (Mansbridge et al., 2012, p. 12). Concerning the outcome of deliberative processes, there are also two alternative ideas: Habermas' claim for a shared consensus and the counter-proposal by Wessler and Schultz (2007, p. 18) arguing for a reasoned dissent, which represents the epistemic function of deliberation (Parkinson \& Mansbridge, 2012, p. 11). A less prominent outcome of deliberative discourses, which is often only implicitly considered, is the emergence and transformation of a society-wide group-bridging collective identity (Mutz, 2008). As Peters suggests "public discourse is a very important mechanism for the production, change and intergenerational transmission of collective identities" (2008a, p. 242). Although identity is not a traditional core element of deliberative theory, in the context of social integration and deep division it should be made a central concern.

From a deliberative perspective, public conflict communication should help citizens to learn about perspectives of other groups in society, and should provide them with sufficient information to form well-grounded 
opinions towards the political issue flowing from group conflicts. The focus of the deliberative perspective on the procedural aspect of democracy is, according to Habermas, a consequence of society's complexity: Instead of focusing on consensual values, complex societies are held together by a consensus on "the procedures for the legitimate enactments of laws and the legitimate exercise of power" (Habermas, 1994a, p. 135). Even if we are not able to point to a generally shared common good - an aspect that is the core of many sociological theories of integration (e.g., Durkheim, 1988; Mead, 1993) as well as communication theories concerned with integration (Schulz, 1997; Vlasic, 2004) - "we at least can point to standards that inhibit ... [one social group] from subsuming the state under its own identity" (O'Flynn, 2006, p. 75). In this case, one social group would equate state identity with their group identity. This would put members of other social groups in a marginal position because it would deny them partaking in national identity without giving up their group identity. In Turkey, for example, the Kurdish people struggle to keep their own identity. One reason is that the dominating group has equated their group identity with the national identity leaving social groups no choice but to assimilate or to resist and be alienated from the society they live in.

We can conclude that of all normative democratic theories the deliberative notion is best suited for divided societies for the following reasons: It prioritizes access to the public sphere for all social actors, ideas and positions, situates discourse on values in the public sphere and recognizes the connection between discourse and identity. Theoretically, this reasonable idea has already been discussed by other scholars (e.g., Dryzek, 2005; Ellis, 2018; Ercan, 2017a; O'Flynn, 2007). Empirical work (see e.g., Caluwaerts \& Deschouwer, 2014; Ercan, 2017b; Steiner et al., 2017; Ugarriza \& Nussio, 2017) has been able to show the positive influence of deliberative face-to-face settings on reconciliation between conflicting groups in divided societies (see Ugarriza \& Caluwaerts 2014 for an overview). However, in these works, the media is often barely mentioned. We aim to fill this gap here.

\section{Integrative Functions of Deliberative Media Content}

We will now take a closer look at the integrative functions of different deliberative criteria. In this context, it is important to mention the Deliberative Quality Index (DQI) developed by Steiner and colleagues (Steenbergen et al., 2003; Steiner, 2012). The DQI was originally developed for face-to-face discussions among political elite actors in parliament and is an established measure for the deliberative quality of discussions. Meanwhile, the DQI has been adapted to various contexts such as discussions among citizens in experimental face-to-face settings (Caluwaerts, 2012; Caluwaerts \& Deschouwer, 2014) or mediated debates (Pilon, 2009). In this article, we aim at defining normative criteria to capture and measure social integration within media content. As we ground these criteria in the normative theories of deliberation some of the criteria discussed below might be quite similar to certain criteria within the DQI (e.g., participation, respect). However, as we focus on social relations between actors and social groups within mediated contexts we also deviate from the DQI in important ways. As already mentioned we include the display of a groupbridging identity as a criterion because this is per definition most relevant for social integration especially in the context of divided societies. Conversely, we do not include the more "classical" argumentation-related criteria of justification and rebuttal for the following reasons:

Justification in its most common understanding refers to the use of argument to support one's claim (Maia, 2012, p. 106). This so-called cognitive-epistemic function of justification (Rinke, 2016b) does not necessarily contribute to mediated social integration: Justified claims do not automatically relate to claims made by other participants in a discourse and they do not necessarily support benevolent claims. A person might justify his or her claim very well while at the same time completely ignoring the claims of other participants, thereby undermining their legitimacy. From a deliberative perspective such an utterance might be valuable, but from an integrative perspective it is much less so. However, justification has been argued to have a social-moral dimension, too, in the sense that it is conditional for mutual respect (Larmore, 1999). In justifying their positions, discussants realize the principle of mutual respect towards other actors. However, empirical evidence suggests that justifications per se might not foster social integration between conflicting groups: Ugarriza and Nussio (2017) show that within face-to-face discussions between members of conflicting groups justification did not necessarily improve attitudes towards the other group. In contrast, it rather "moves people's attention away from the empathy stimuli that ... lead to the desired changes in attitudes" (Ugarriza \& Nussio, 2017, p. 15).

We also propose rebuttal to be less important for mediated social integration, albeit less for theoretical but more for empirical reasons. Rebuttal can be understood as referring to and arguing against positions, actors or ideas that one opposes (Ferree et al., 2002, p. 241). Due to their referential nature, rebuttals do have a strong integrative potential. However, empirical research concerning the deliberative quality of media content has shown that rebuttals hardly exist within mass media coverage (see e.g., Ferree et al., 2002; Rinke et al., 2013). Hence, it might be an important criterion for other contexts such as faceto-face discussions or elite debate, but much less so for mediated debates.

To conclude, we do not conceive of justification and rebuttal as central concerns in a deliberative conception of mediated social integration. But what are the core criteria of this conception that we retain?

\section{Inclusiveness/Accessibility}

Inclusiveness or accessibility refers to the question of who is heard within a mediated discourse (Maia, 2012, p. 106). A broad inclusion of actors, perspectives, ideas, opinions, and issues is desirable from a deliberative, but also from a social integration perspective: Only when a broad range of speakers, opinions, and perspectives is included, can social relationships between different groups and individuals be formed. Particularly in the context of divided societies the issue of inclusiveness is highly sensitive as the exclusion of 
one or more conflicting groups from a (mediated) discourse might result in even deeper divisions and therefore would not serve social integration. Thus, a setting in which former antagonists come together to discuss a controversial issue might itself be a very important first step (cf. Ugarriza \& Nussio, 2002). Inclusiveness can therefore be seen as the basic condition for mediated social integration and as a necessary, but probably not sufficient, criterion. Table $\mathbf{1}$ in the next section provides an exemplary specification of inclusiveness for two types of mediated discourses.

\section{Reciprocity/Responsiveness}

Reciprocity or responsiveness addresses the interactions and relations between participants of a discourse and their claims (Maia, 2012, p. 107). This aspect of deliberative discourses speaks directly to mediated social integration as it addresses its key aspect: the relationships between social actors as well as the positions/ideas/claims they stand for or relate to. Häussler (2012) also recognizes the integrative potential of responsiveness "working not only as a measure of dialogicality but even more as an indicator of discursive integration and recognition of the other" (p. 132). Thus, responsiveness can be seen as the essence of social integration: If actors from different groups publicly engage with each other a major step towards social integration is reached.

Empirical research has also offered insights on the benefits of responsiveness: Mutz (2006), for example, showed that the exposure of discussants to oppositional views can lead to more respect towards opposing opinions. Further insights are provided by the intergroup contact theory. According to the contact hypothesis (Allport, 1954), direct as well as mediated social contact between members of conflicting groups are important to reduce prejudices and social conflict and to foster positive attitudes towards the other group as a whole. Due to the size and complexity of today's societies, the primary source for social contact between conflicting groups is mass media coverage (Mutz \& Goldman, 2010). In divided societies, such acts of mediated responsiveness between opposing social groups are central because in engaging with each other a first step towards a social relation between the different social groups is taken. The responsiveness of actors within media coverage can therefore be seen as a necessary, though not sufficient, condition for social integrative processes perceived through the media. However, responsiveness can vary in intensity. Häussler (2017) offers some differentiations on how responsiveness in mediated discourses might manifest itself; an exemplary specification for the purpose of empirical measurement is provided in Table $\mathbf{1}$.

\section{Civility/Mutual Respect}

Civility or mutual respect refers to the way actors should speak to each other. Of the two, civility is the narrower concept and refers to the use of an acceptable and nonoffending language (cf., Cinalli \& O'Flynn, 2014; Coe et al., 2014). From a deliberative perspective, it is desirable

Table 1: Deliberative features conducive to fostering social integration in two forms of mediated discourse.

\begin{tabular}{ll}
$\begin{array}{l}\text { Deliberative } \\
\text { feature }\end{array}$ & Newspaper article \\
\hline Inclusiveness & $\begin{array}{l}\text { Speakers from opposing groups are quoted directly } \\
\text { or indirectly } \\
\text { Positions from opposing groups are presented in } \\
\text { the same article }\end{array}$ \\
Responsiveness & $\begin{array}{l}\text { Quotes from speakers that include direct } \\
\text { substantive responses to speakers/positions from } \\
\text { opposing groups are included in the article. }\end{array}$ \\
& $\begin{array}{l}\text { Speakers from opposing groups are quoted in such } \\
\text { a way that their statements substantively address } \\
\text { each other even though their quotes do not } \\
\text { contain such references. }\end{array}$
\end{tabular}

Mutual respect Quotes from speakers do not contain degradations of opposing speakers and/or their positions Articles do not contain a degrading style of writing

\section{Group-bridging identities}

\section{Facebook discussions}

Speakers from opposing groups contribute comments to the discussion Comments include positions from opposing groups

Facebook users use the "reply-function" to engage with comments from users that belong to the opposing group or contain opposing positions.

Facebook users address users from opposing groups and/or their positions directly.

Facebook users address the content of comments provided by users from opposing groups and/or their positions substantively in their own comments.

Comments do not contain verbal or non-verbal degrading references to members of the opposing group. Moderators and/or netiquettes set communication rules which sanction violations of mutual respect.

Facebook users are careful to ensure that their comments contain references to speakers form opposing groups and do not violate the norm of mutual respect.

Facebook users refrain from highlighting irreconcilable group characteristics while talking about substantive disagreements.

Facebook users include group- bridging identity markers in their posts and comments.

Note: While the normative criteria are applicable to all stages of the communicative process the specifications given in this table are formulated to apply to media products and are measured on an article/comment level. 
because it enables participants to focus on substance and to engage in a rational discourse in which all arguments are considered equally well. Mutual respect is the broader but also less prominent concept that is more concerned with the general attitude toward other actors. Ferree et al. describe it as "a form of agreeing to disagree" (2002, p. 218). It "requires a favorable attitude toward, and constructive interaction with the persons with whom one disagrees" (Gutmann \& Thompson, 1997, p. 79). The deliberative demand for civility has been excessively criticized due to its alleged exclusiveness towards less privileged groups in society. ${ }^{2}$ Concerning its integrative potential, we agree with the critics in so far as we do not see civility as a sufficient criterion for mediated discourses. However, mutual respect is, in our view, a necessary condition for a discourse to be integrative. The interaction between discussants should be characterized by a general acceptance of other actors and their positions/claims/ ideas as legitimate opposition and by the willingness to engage with them.

For example, an actor can state in a very civil manner that the arguments of a social group should be ignored because their claims are not worth being discussed (Papacharissi, 2004). The actor would show civility on the surface but disrespect towards the social group because $\mathrm{s} /$ he would exclude the group and its claims from the discussion. Mutual respect therefore is a very useful criterion in order to determine statements that clearly do not serve social integration because they are exclusionary. In this respect, the role of journalists - and individual online users - in media debates is not confined to avoiding degradations of opposing speakers, but to actively flagging such communicative transgressions in order to improve the aggregate level of mutual respect (Ziegele et al., 2018).

Empirical research also hints to the importance of mutual respect as a qualitative element in addition to the more structure-based criterion of responsiveness: Hargittai, Gallo, and Kane (2007), for example, show that crossbridging communication - i.e., communicative acts across ideological camps - in an online environment is a) not very common and b) not positive per se because it can be used to disparage the opposing side (for similar results see e.g., Shaw \& Benkler, 2012; Sunstein, 2001). Research on the contact hypothesis comes to a similar conclusion: Following Paolini et. al. (2010), for example, contact between different social groups per se does not reduce prejudices. The form of the contact is the crucial aspect: According to Paolini and colleagues negative intergroup contact with individuals from the other social group is transferred to all members of that outgroup and consequently, prejudices toward the outgroup as a whole increase. Therefore, responsiveness accompanied by mutual respect can be seen as one of the most central elements of social integration. One prominent example of operationalizing mutual respect (and incivility) in mediated discourses, which might guide further research, is provided by Berry and Sobieraj (2014) in their study of newspaper, radio and television items. In Table 1 we use the term "degrading style" to subsume all possible violations of mutual respect.

\section{Group-bridging Identities}

The concept of identity is usually not found among the traditional core elements of deliberative theory. This lack of recognition has often been criticized by representatives of feminist democratic theories (cf. Fraser, 1990). However, the concept of identity is rather important for social integration. Therefore, it is necessary to define it more precisely and locate it within the deliberative framework. We follow Tajfel in defining identity as "that part of the individual's self-concept which derives from his knowledge of his membership of a social group (or groups) together with the value and emotional significance attached to this membership" (1981, p. 255). Identities therefore do not exist and develop within an individual: Instead identities are "publicly formed and they are constituted in large part by ... relationships to others, both to other individuals and to organizations and institutions" (Laden, 2001, p. 90).

This idea of conceptualizing identity as a network of relationships to other social actors can be traced back to classical sociological works (e.g., Simmel, 1890, pp. 100-116). Similar to Peters (2008a), Laden (2001) defines deliberation as a central mechanism for the construction of an identity as a democratic citizen:

Through engaging in the ongoing project of legitimating political principles and policies via reasonable political deliberation, members of a political society come to share an identity as citizens [emphasis added] and give that identity a determinate content (Laden, 2001, p. 203).

This understanding implies that the nature of the relationships constituting an identity as citizens is communicative. The underlying mechanism that transforms communicative relationships into a shared identity is that "in the course of forming relationships with others, we come to share a set of reasons with them" (2001, p. 89). Based on this set of shared reasons political issues are then processed. By taking part in this process and eventually sharing common reasons with other social actors a shared understanding of what it means to be a citizen emerges - an identity as citizens. In other words, the form in which identities are constructed plays a constitutive role for identity formation.

Following Laden (2001), communicative relationships need to be responsive to count as such. A qualitative element that defines them however is not spelled out clearly. We will therefore draw on our arguments presented above and use mutual respect as a qualitative element for identity-generating communicative relationships. Hence, a communicative relationship that transforms into a shared identity needs to fulfill the two deliberative criteria of responsiveness and mutual respect described above simultaneously.

As Laden (2001) points out further, a deliberative discourse enables citizens to shift their focus from groupspecific identities to overarching group-bridging identities as members of the respective political community. A similar proposal can be found in lyengar et al. (2019) 
regarding the reduction of affective polarization in the U.S. According to them, Democrats and Republicans may overcome their partisan identities by focusing on their shared identity as American citizens.

Thus, focusing on overarching group-bridging identities can enable members of the different groups to experience commonalities. In Table $\mathbf{1}$ we provide some exemplary specifications for two types of mediated discourses and point to studies that might be helpful for further researchers in operationalizing these criteria. An operationalization of group-bridging identities for mediated discourses can be found, for example in Adam (2014) or Wessler et al. (2008).

To conclude, even though identity is not one of the traditional criteria of a deliberative discourse, it can be seen as a crucial element nevertheless, which is especially important in the context of social integration and the processing of deep conflicts and affective polarization alike: As Peters states, the formation of an identity and social integration are aspects of the same process (1993, p. 116). Thus public deliberation, social integration, ${ }^{3}$ and the construction of group-bridging identities as democratic citizens are closely interlinked.

\section{Mediated Social Integration in Two Forms of Mediated Discourse}

In Table 1 we offer an exemplary specification of the four indicators discussed in this paper. To show the broad applicability of our four central criteria we cover two very different forms of mediated discourse: newspaper articles as a form of professional mass-mediated discourse and Facebook discussions representing user-generated online discussion on social media. ${ }^{4}$

In the case of newspaper articles, the main responsibility in promoting features that might foster social integration lies with the journalists producing the content. Regarding the first indicator - inclusiveness - journalists decide which speakers and/or positions get heard and which do not. It lies in their responsibility to include speakers and/or positions from opposing social groups. In the context of user-generated discussion on social media, the content is much less controlled by professionals such as journalists: Inclusiveness is usually not guaranteed or artificially constructed as it might be for mass-mediated journalism. Instead, Facebook users of opposing groups need to participate actively by posting comments in an online discussion, or they need to rely on others to include their positions for them.

Responsiveness can manifest itself in newspaper articles in two major ways. First, journalists can select and include direct quotes by speakers from opposing groups that already contain references to speakers and/ or positions from the opposing groups. Second, they can also construct responsiveness by arranging quotes in a way that for the reader they substantively relate to each other. For Facebook discussions such responsiveness can also be achieved in different ways: To distinguish between the two major forms of responsiveness we adopt Trénel's (2004) differentiation between formal and substantive responsiveness. Formal responsiveness captures platform-specific features that enable participants to link their contributions to other participants like using the "reply"-function in Facebook discussions or using the name of another participant in the comment thereby addressing them directly. Substantive responsiveness on the other hand refers to references to the actual content of the contributions made by other participants. Both forms of responsiveness might contribute to social integration.

The third indicator captures a qualitative moment of communication: mutual respect. Within newspaper articles mutual respect can be induced by journalists - if not provided by their sources in the first place - by switching to indirect speech or not including quotes that contain foul and disrespectful language or by actively condemning disrespectful behavior. At the same time, journalists can refrain from using degrading language in their articles as well. On social networks such as Facebook users have again different options in displaying mutual respect: Facebook users can refrain from including verbal (e.g., foul language) as well as non-verbal (e.g., emojis, gifs, videos etc.) means of degrading others in their comments directed to other participants and/or their positions. Mutual respect can also be supported through moderators whose positive influence on the deliberative quality of online debates has been shown in various studies (for an overview see Friess \& Eilders, 2015, pp. 326-327). Another aspect of mutual respect is the existence of so-called netiquettes in which standards for "acceptable language" as well as sanctions against violations are defined.

In newspaper articles, journalists can support the emergence of group-bridging identities by combining the two features responsiveness and mutual respect as we have argued above. Furthermore, journalists can foster group-bridging identities by avoiding strong markers of separation between different conflict groups. Or they can include identity markers of group-bridging identities like "we", "ours", "us", as for example suggested by Wessler and colleagues (2008). This can either be done by the journalists themselves but also by including quotes that contain such markers. In the context of Facebook discussions, group-bridging identities are fostered if user comments contain references to speakers and/or their positions from opposing groups and do not violate the norm of mutual respect. At the same time, they can refrain from pronouncing irreconcilable group characteristics in discussions on substantive disagreement. Finally, the inclusion of overarching identity markers in posts and comments can also contribute to the formation of groupbridging identities.

\section{Conclusion}

In this paper, we first identified conflict communication as the central mode of communication in modern societies, especially in divided societies. Drawing on sociological theories, we made a point for the positive potential of robust but contained conflicts for social integration. We then drew on deliberative theories of public communication and identified four desirable qualities of mediated discourse that have integrative potential and 
that may, in the long run, help mitigate deep divides: Inclusiveness of actors and positions is the basic condition. If particular actors or positions are not included in mediated public discourse their claims or positions might as well not exist at all. They might be taken up in smaller face-to-face settings but if they do not transmit to the mediated public sphere they implode and are not included in any form of social integration. Responsiveness, which is the act of referring to another actor or position, is at the core of an integrative mediated discourse: It creates, by definition, communicative relationships between social actors or positions of social actors and therefore speaks directly to the concept of social integration. However, responsiveness on its own can also be used to denigrate the position or person of another speaker within mediated discourse. This clearly does not serve mediated social integration; it might actually lead to an escalation of the conflict instead. Therefore, a qualitative element is necessary to separate beneficial responsiveness from such responses that do more harm than good: Mutual respect serves this particular function because it "allows citizens to honestly consider the merits of all sides' arguments and accept the general legitimacy of political opposition" (Rinke, 2016a).

In addition, we have stated that communicative structures formed in a deliberative discourse between actors contribute to commonly shared, group-bridging identities. In the context of deep divides and ethnopolitical conflict, group identities play a central role as these forms of conflict actually are in part conflicts of competing group identities (Ellis, 2012; 2018). It is therefore important to understand that identities are no fixed social categories. Instead, they are flexible and constructed through communication (Laden, 2001). Communication can therefore deconstruct them and construct new, more inclusive identities. The form of communication that is conducive to the construction of such shared identities is inclusive and characterized by a responsive exchange based on mutual respect.

As this paper presents a theoretical framework for capturing mediated social integration, it cannot specify how likely it is that media content fulfills these normative criteria. It remains an empirical question whether an integrated mediated discourse as we have described it above truly leads to social integration in people's lives beyond the realm of public communication. Nevertheless, we suggest that mediated conflict communication that is shaped by the criteria specified will help overcome cleavages and integrate groups in a broader context without submerging their distinctiveness as both social integration and public deliberation are part of the same process (Peters, 1993).

The normative criteria spelled out above are universal in the sense that they are applicable to all forms of mediated discourse and all three stages of the communication process: On the production side, these variables could be used to investigate to what extent journalists or users of online platforms consider these criteria while reporting or writing on conflict. It might also be a useful tool for journalists if they want to report in a more integrative way and might serve them as a guideline in their daily line of work. Regarding the products of mediated discourse, the normative criteria can be used to evaluate the integrative potential of media content. However, depending on the context of investigation the empirical meaning of the respective criteria needs to be specified further.

Concerning the effect on citizens and their actual perception of other social groups within their society the four criteria named above can serve as a starting point to explore whether and how a more or less integrated mediated discourse influences the social integration of different groups within a society characterized by deep conflict. We hope that further studies will take up this task of empirical investigation. Based on such empirical knowledge, our conception of the integrative functions of mediated conflict communication might then also be connected back to the journalism reform movements such as "public journalism" or "constructive journalism" mentioned above and inspire initiatives for discursive intervention on social media.

While there is a growing body of literature that investigates, for example, the conditions under which discursive interventions in online discussions occur (Kalch \& Naab, 2017; Naab et al., 2016), the consequences of these insights for mediated social integration need yet to be spelled out. The same holds true for social media initiatives such as the Swedish \#jagärhär or the German \#ichbinhier Facebook groups, which aim at improving the quality and the communicative style of online discussions by actively engaging with users who post comments that contain outrage and/or hate speech (Ley, 2018). The connection of these initiatives to achieving or fostering mediated social integration constitutes an exciting focus for future research.

\section{Notes}

${ }^{1}$ Parts of this section are based on Wessler (2002).

${ }^{2}$ In the past, the call for civility has been the central aspect of criticism by scholars advocating the agonistic model of democracy (cf. Mouffe, 1999; Sanders, 1997) but also a point of discussion among deliberative scholars (cf. Habermas, 1996; Young, 1996) themselves. For a more detailed discussion of this development see Wessler et al. (2016).

${ }^{3}$ Peters (1993, p. 208) names this process "political integration", which refers to the creation of an overarching form of collective identity and the emergence of society-wide solidarity that bridges particular group identities and interests.

${ }^{4}$ Some of these specifications concerning massmediated journalism are based on Wessler (2008).

\section{Competing Interests}

The authors have no competing interests to declare.

\section{Author Contribution}

Both authors have contributed substantially to the manuscript and meet all of the recommended criteria of authorship suggested by the Journal of Deliberative Democracy. 


\section{References}

Adam, S. (2014). Do mass media portray Europe as a community? An empirical analysis of the integration potential of the German and French debates on EU enlargement and a common Constitution. Javnost The Public, 15, 91-112. DOI: https://doi.org/10.1080 /13183222.2008.11008966

Ahva, L. (2012). Public journalism and professional reflexivity. Journalism, 14, 790-806. DOI: https://doi. org/10.1177/1464884912455895

Allport, G. W. (1954). The nature of prejudice. AddisonWesley Pub. Co.

Baker, C. E. (2002). Media, markets, and democracy. Cambridge University Press. DOI: https://doi. org/10.1017/CBO9780511613227

Berry, J. M., \& Sobieraj, S. (2014). The outrage industry: Political opinion media and the new incivility. Studies in postwar American political development. Oxford University Press.

Bro, P. (2019). Constructive journalism: Proponents, precedents, and principles. Journalism, 20, 504-519. DOI: https://doi.org/10.1177/1464884918770523

Brüggemann, M., Hepp, A., Kleinen-von Königslöw, K., \& Wessler, H. (2009). Transnationale Öffentlichkeit in Europa: Forschungsstand und Perspektiven. Publizistik, 54(3), 391-414. DOI: https://doi.org/10.1007/s11616009-0059-4

Caluwaerts, D. (2012). Confrontation and communication: Deliberative democracy in divided Belgium. Peter Lang.

Caluwaerts, D., \& Deschouwer, K. (2014). Building bridges across political divides: Experiments on deliberative democracy in deeply divided Belgium. European Political Science Review, 6, 427-450. DOI: https://doi.org/10.1017/S1755773913000179

Cinalli, M., \& O'Flynn, I. (2014). Public deliberation, network analysis and the political integration of Muslims in Britain. The British Journal of Politics \& International Relations, 16, 428-451. DOI: https://doi. org/10.1111/1467-856X.12003

Coe, K., Kenski, K., \& Rains, S. A. (2014). Online and uncivil? Patterns and determinants of incivility in newspaper website comments. Journal of Communication, 64, 658-679. DOI: https://doi. org/10.1111/jcom.12104

Dryzek, J. S. (2005). Deliberative democracy in divided societies: Alternatives to agonism and analgesia. Political Theory, 33, 218-242. DOI: https://doi. org/10.1177/0090591704268372

Dubiel, H. (1997). Unversöhnlichkeit und Demokratie. In W. Heitmeyer (Ed.), Was hält die Gesellschaft zusammen? (pp. 425-444). Suhrkamp.

Dubiel, H. (1999). Integration durch Konflikt? In J. Friedrichs \& W. Jagodzinski (Eds.), Sonderheft 39 der Kölner Zeitschrift für Soziologie und Sozialpsychologie. Soziale Integration (pp. 132-143). Westdeutscher Verlag. DOI: https://doi.org/10.1007/978-3-32283345-7_6

Durkheim, É. (1988). Über soziale Arbeitsteilung: Studie über die Organisation höherer Gesellschaften (2nd ed.). Suhrkamp.
Ellis, D. G. (2018). Building a theory of communication and ethnopolitical conflict. Communication Monographs, 86(1), 68-87. DOI: https://doi.org/10.1080/0363775 1.2018 .1507044

Ercan, S. A. (2017a). Engaging with extremism in a multicultural society: A deliberative democratic approach. Journal of Peacebuilding \& Development, 12(2), 9-21. DOI: https://doi.org/10.1080/15423166 .2017 .1314791

Ercan, S. A. (2017b). From polarisation to pluralisation: A deliberative approach to illiberal cultures. International Political Science Review, 38, 114-127. DOI: https://doi. org/10.1177/0192512115619465

Ferree, M. M., Gamson, W. A., Gerhards, J., \& Rucht, D. (2002). Shaping abortion discourse: Democracy and the public sphere in Germany and the United States. Communication, society, and politics. Cambridge University Press. DOI: https://doi.org/10.1017/ CBO9780511613685

Fraser, N. (1990). The uses and abuses of French discourse theories for feminist politics. boundary 2, 17(2), 82-101. DOI: https://doi.org/10.2307/303566

Friess, D., \& Eilders, C. (2015). A systematic review of online deliberation research. Policy \& Internet, 7, 319339. DOI: https://doi.org/10.1002/poi3.95

Gutmann, A., \& Thompson, D. F. (1997). Democracy and disagreement (2nd ed.). Belknap Press of Harvard University Press.

Habermas, J. (1994a). Struggles for recognition in the democratic constitutional state. In C. Taylor \& A. Gutmann(Eds.), Multiculturalism:Examining the politics of recognition (pp. 107-148). Princeton University Press. DOI: https://doi.org/10.1515/9781400821402008

Habermas, J. (1994b). Three normative models of democracy. Constellations, 1, 1-10. DOI: https://doi. org/10.1111/j.1467-8675.1994.tb00001.x

Habermas, J. (1996). Between facts and norms: Contributions to a discourse theory of law and democracy. Studies in contemporary German social thought. MIT Press. DOI: https://doi.org/10.7551/ mitpress/1564.001.0001

Hargittai, E., Gallo, J., \& Kane, M. (2007). Crossideological discussions among conservative and liberal bloggers. Public Choice, 134, 67-86. DOI: https://doi. org/10.1007/s11127-007-9201-x

Häussler, T. (2012). Contest, Conflict, and Consensus [Doctoral Dissertation]. University of Bern.

Häussler, T. (2017). The media and the public sphere: $A$ deliberative model of democracy. Routledge. DOI: https://doi.org/10.4324/9780203728642

Held, D. (2006). Models of democracy (3. ed.). Stanford Univ. Press.

Hermans, L., \& Gyldensted, C. (2018). Elements of constructive journalism: Characteristics, practical application and audience valuation. Journalism, 20, 535-551. DOI: https://doi. org/10.1177/1464884918770537

Hirschman, A. O. (1994). Wieviel Gemeinsinn braucht die liberale Gesellschaft? Leviathan, 22, 293-304. 
Imbusch, P., \& Rucht, D. (2005). Integration und Desintegration in modernen Gesellschaften. In W. Heitmeyer \& P. Imbusch (Eds.), Integrationspotenziale einer modernen Gesellschaft (pp. 13-71). VS Verlag für Sozialwissenschaften. DOI: https://doi. org/10.1007/978-3-322-80502-7_1

Integrate. (2017). In Oxford Dictionary. Oxford: Oxford University Press. Retrieved from https:// en.oxforddictionaries.com/definition/integrate

Iyengar, S., Lelkes, Y., Levendusky, M., Malhotra, N., \& Westwood, S. J. (2019). The origins and consequences of affective polarization in the United States. Annual Review of Political Science, 22, 129-146. DOI: https:// doi.org/10.1146/annurev-polisci-051117-073034

Kalch, A., \&Naab, T. K. (2017). Replying, disliking, flagging: How users engage with uncivil and impolite comments on news sites. Studies in Communication | Media, 6, 395-419. DOI: https://doi.org/10.5771/2192-40072017-4-395

Kanra, B. (2016). Islam, democracy and dialogue in Turkey: Deliberating in divided societies. Taylor and Francis. DOI: https://doi.org/10.4324/9781315589985

Keeble, R. L., Tulloch, J., \& Zollmann, F. (2010). Peace journalism, war and conflict resolution. Peter Lang. DOI: https://doi.org/10.3726/978-1-4539-0104-5

Kellow, C. L., \& Steeves, H. L. (1998). The Role of radio in the Rwandan genocide. Journal of Communication, 48, 107-128. DOI: https://doi. org/10.1111/j.1460-2466.1998.tb02762.x

Kristof, N. D. (2003, March 4). God, satan and the media. New York Times. Retrieved from http://www.nytimes. com/2003/03/04/opinion/god-satan-and-the-media. html

Laden, A. S. (2001). Reasonably radical: Deliberative liberalism and the politics of identity. Cornell Univ. Press.

Larmore, C. (1999). The moral basis of political liberalism. The Journal of Philosophy, 96, 599-625. DOI: https:// doi.org/10.2307/2564695

Ley, H. (2018). \#ichbinhier: Zusammen gegen Fake News und Hass im Netz. DuMont.

Lockwood, D. (1970). Soziale Integration und Systemintegration. In W. Zapf (Ed.), Theorien des sozialen Wandels (2nd ed., pp. 124-137). Kiepenheuer und Witsch.

Luhmann, N. (1996). Die Realität der Massenmedien (2nd ed.). Westdeutscher Verlag. DOI: https://doi. org/10.1007/978-3-663-01103-3

Luhmann, N. (2008). Die Soziologie und der Mensch (3rd ed.). VS Verlag für Sozialwissenschaften.

Lynch, J., \& Galtung, J. (2010). Reporting conflict: New directions in peace journalism. University of Queensland.

Maia, R. C. M. (2012). Deliberation, the media and political talk. Hampton Press.

Mansbridge, J. J., Bohman, J., Chambers, S., Christiano, T., Fung, A., Parkinson, J., ... Warren, M. E. (2012). A systemic approach to deliberative democracy. In J. Parkinson \& J. J. Mansbridge (Eds.), Theories of institutional design. Deliberative systems: Deliberative democracy at the large scale (pp. 1-26). Cambridge University Press. DOI: https://doi.org/10.1017/ CB09781139178914.002

Mast, J., Coesemans, R., \& Temmerman, M. (2019). Constructive journalism: Concepts, practices, and discourses. Journalism, 20, 492-503. DOI: https://doi. org/10.1177/1464884918770885

Mead, G. H. (1993). Geist, Identität und Gesellschaft aus der Sicht des Sozialbehaviorismus (9. ed.). Suhrkamp.

Mouffe, C. (1999). Deliberative democracy or agonistic pluralism. Social Research, 66, 745-758. Retrieved from http://www.jstor.org/stable/40971349

Mouffe, C. (2013). Agonistics: Thinking the world politically. Verso.

Mutz, D. C. (2006). Hearing the other side: Deliberative versus participatory democracy. Cambridge University Press. DOI: https://doi.org/10.1017/ CBO9780511617201

Mutz, D. C. (2008). Is deliberative democracy a falsifiable theory? Annual Review of Political Science, 11, 521-538. DOI: https://doi.org/10.1146/annurev. polisci.11.081306.070308

Mutz, D. C., \& Goldman, S. K. (2010). Mass Media. In Dovidio, John, F., M. Hewstone, P. Glick, \& V. M. Esses (Eds.), The SAGE handbook of prejudice, stereotyping and discrimination (pp. 241-258). SAGE Publications Ltd. DOI: https://doi.org/10.4135/9781446200919. n15

Naab, T. K., Kalch, A., \& Meitz, T. G. K. (2016). Flagging uncivil user comments: Effects of intervention information, type of victim, and response comments on bystander behavior. New Media \& Society, 20, 777-795. DOI: https://doi.org/10.1177/1461444816670923

O'Flynn, I. (2006). Deliberative democracy and divided societies. Edinburgh University Press. DOI: https://doi. org/10.3366/edinburgh/9780748621446.001.0001

O'Flynn, I. (2007). Divided societies and deliberative democracy. British Journal of Political Science, 37, 731-751. DOI: https://doi.org/10.1017/ S0007123407000397

Page, B. I. (1996). Who deliberates? Mass media in modern democracy. University of Chicago Press.

Paolini, S., Harwood, J., \& Rubin, M. (2010). Negative intergroup contact makes group memberships salient: Explaining why intergroup conflict endures. Personality \& Social Psychology Bulletin, 36, 1723-1738. DOI: https://doi.org/10.1177/0146167210388667

Papacharissi, Z. (2004). Democracy online: civility, politeness, and the democratic potential of online political discussion groups. New Media \& Society, 6, 259-283. DOI: https://doi. org/10.1177/1461444804041444

Parkinson, J., \& Mansbridge, J. J. (Eds.) (2012). Deliberative systems: Deliberative democracy at the large scale. Theories of institutional design. Cambridge University Press. DOI: https://doi.org/10.1017/ CBO9781139178914

Parsons, T. (1958). Essays in sociological theory. Free Press. Peters, B. (1993). Die Integration moderner Gesellschaften. Suhrkamp. 
Peters, B. (2008a). Public discourse, identity and the problem of democratic legitimacy (2005). In $\mathrm{H}$. Wessler (Ed.), Public deliberation and public culture: The writings of Bernhard Peters, 1993-2005 (pp. 213-254). Palgrave Macmillan.

Peters, B. (2008b). The functional capacity of contemporary public spheres (2002). In H. Wessler (Ed.), Public deliberation and public culture: The writings of Bernhard Peters, 1993-2005 (pp. 121-133). Palgrave Macmillan.

Pilon, D. (2009). Investigating media as a deliberative space: Newspaper opinions about voting systems in the 2007 Ontario provincial referendum. Canadian Political Science Review, 3(3), 1-23.

Rinke, E. M. (2016a). Mediated deliberation. In Gianpietro Mazzoleni (Ed.), International encyclopedia of political communication (pp. 1-15). John Whiley \& Sons. DOI: https://doi.org/10.1002/9781118541555.wbiepc189

Rinke, E. M. (2016b). The impact of sound-bite journalism on public argument. Journal of Communication, 66, 625-645. DOI: https://doi.org/10.1111/jcom.12246

Rinke, E. M., Wessler, H., Löb, C., \& Weinmann, C. (2013). Deliberative qualities of generic news frames: Assessing the democratic value of strategic game and contestation framing in election campaign coverage. Political Communication, 30, 474-494. DOI: https:// doi.org/10.1080/10584609.2012.737432

Rosen, J., Merritt, D., \& Austin, L. (1997). Public journalism: Theory and practice - lessons from experience. Foundation Press.

Sanders, L. M. (1997). Against deliberation. Political Theory, 25, 347-376. DOI: https://doi. org/10.1177/0090591797025003002

Schulz, W. (1997). Politische Kommunikation: Theoretische Ansätze und Ergebnisse empirischer Forschung zur Rolle der Massenmedien in der Politik. Westdeutscher Verlag.

Shaw, A., \& Benkler, Y. (2012). A tale of two blogospheres: Discursive practices on the left and right. American Behavioral Scientist, 56(4), 459-487. DOI: https://doi. org/10.1177/0002764211433793

Simmel, G. (1890). Über sociale Differenzierung: Sociologische und psychologische Untersuchungen. Duncker \& Humblot. DOI: https://doi. org/10.3790/978-3-428-57712-5

Steenbergen, M. R., Bächtiger, A., Spörndli, M., \& Steiner, J. (2003). Measuring political deliberation: A discourse quality index. Comparative European Politics, 1, 21-48. DOI: https://doi.org/10.1057/palgrave. cep. 6110002

Steiner, J. (2012). The foundations of deliberative democracy: Empirical research and normative implications. Cambridge University Press. DOI: https:// doi.org/10.1017/CBO9781139057486

Steiner, J., Jaramillo, M. C., Maia, R. C. M., \& Mameli, S. (2017). Deliberation across deeply divided societies. Cambridge University Press. DOI: https://doi. org/10.1017/9781316941591

Sunstein, C. R. (2001). Republic.com. Princeton, N.J.: Princeton University Press.
Tajfel, H. (1981). Human groups and social categories: Studies in social psychology. Cambridge University Press.

Thompson, A., \& Annan, K. A. (Eds.) (2007). The Media and the Rwanda genocide. Pluto Press; Fountain Publishers; International Development Research Centre.

Trénel, M. (2004). Measuring the deliberativeness of online discussions: Coding scheme 2.2. Unpublished paper, Social Science Research Center Berlin, Germany. Retrieved from http://citeseerx.ist.psu.edu/viewdoc/ download?doi=10.1.1.196.7832\&rep=rep1\&type=pdf

Ugarriza, J., \& Caluwaerts, D. (Eds.) (2014). Democratic deliberation in deeply divided societies: From conflict to common ground. Palgrave Macmillan. DOI: https://doi. org/10.1057/9781137357816

Ugarriza, J. E., \& Nussio, E. (2017). The effect of perspective-giving on postconflict reconciliation: An experimental approach. Political Psychology, 38(1), 3-19. DOI: https://doi.org/10.1111/pops.12324

Vlasic, A. (2004). Die Integrationsfunktion der Massenmedien: Begriffsgeschichte, Modelle, Operationalisierung.VSVerlagfürSozialwissenschaften. DOI: https://doi.org/10.1007/978-3-322-80546-1

Wessler, H. (2002). Multiple Differenzierung und kommunikative Integration: Symbolische Gemeinschaften und Medien. In K. Imhof (Ed.), Integration und Medien (pp. 56-76). Westdeutscher Verlag. DOI: https://doi.org/10.1007/978-3-32297101-2_5

Wessler, H. (2008). Investigating deliberativeness comparatively. Political Communication, 25, 1-22. DOI: https://doi.org/10.1080/10584600701807752

Wessler, H. (2018). Habermas and the media. Polity Press. Wessler, H., Peters, B., Brüggemann, M., Kleinen-von Königslöw, K., \& Sifft, S. (2008). Transnationalization of public spheres. Palgrave Macmillan. DOI: https://doi. org/10.1057/9780230229839

Wessler, H., Rinke, E. M., \& Löb, C. (2016). Should we be Charlie ? A deliberative take on religion and secularism in mediated public spheres. Journal of Communication, 66, 314-327. DOI: https://doi. org/10.1111/jcom.12213

Wolfsfeld, G. (2004). Media and the path to peace. Communication, society, and politics. Cambridge University Press. DOI: https://doi.org/10.1017/ CBO9780511489105

Young, I. M. (1996). Communication and the other: Beyond deliberative democracy. In S. Benhabib (Ed.), Democracy and difference: Contesting the boundaries of the political (pp. 120-135). Princeton University Press. DOI: https://doi.org/10.1515/9780691234168007

Ziegele, M., Jost, P., Bormann, M., \& Heinbach, D. (2018). Journalistic counter-voices in comment sections: Patterns, determinants, and potential consequences of interactive moderation of uncivil user comments. Studies in Communication|Media, 7, 525-554. DOI: https://doi.org/10.5771/2192-40072018-4-525 
How to cite this article: Löb, C., \& Wessler, H. (2021). Mediated Deliberation in Deep Conflicts: How Might Deliberative Media Content Contribute to Social Integration Across Deep Divides?. Journal of Deliberative Democracy, 17(2), pp. 69-80. DOI: https:// doi.org/10.16997/jdd.981

Copyright: ( $) 2021$ The Author(s). This is an open-access article distributed under the terms of the Creative Commons Attribution 4.0 International License (CC-BY 4.0), which permits unrestricted use, distribution, and reproduction in any medium, provided the original author and source are credited. See http://creativecommons.org/licenses/by/4.0/. 